\title{
THE DEBATE ON
}

\section{BLACK CIVIL RIGHTS}

\section{IN AMERICA}

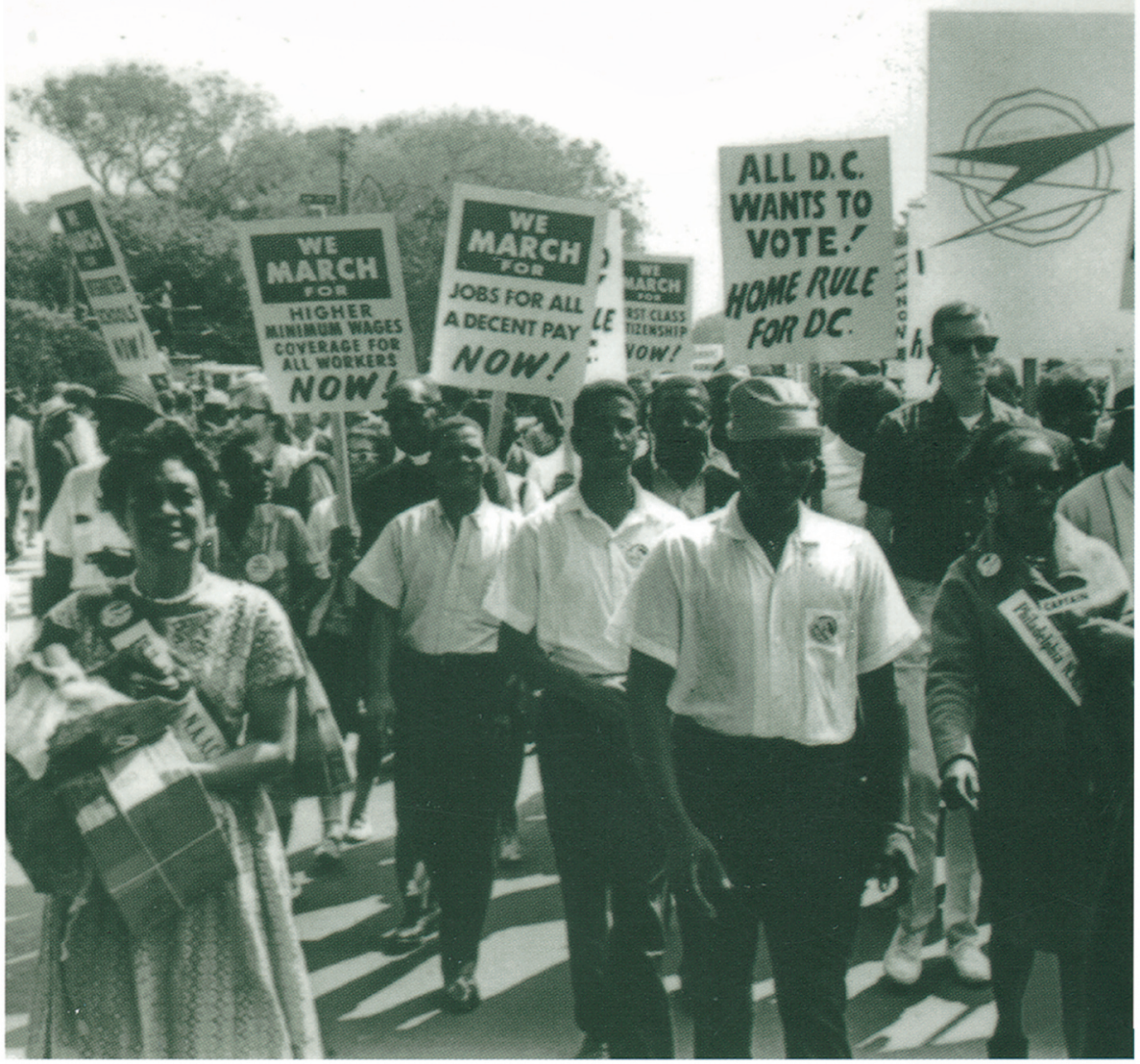


Issues in Historiography

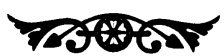

The Debate on Black Civil Rights in America

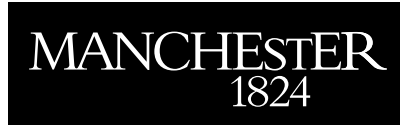

Manchester University Press 
Issues in Historiography

General editor

R. C. RICHARDSON

University of Winchester

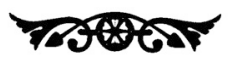

Already published

The Debate on the Norman Conquest

Marjorie Chibnall

The Debate on the French Revolution

Peter Davies

Debates on the Holocaust

Tom Lawson

The Debate on the American Revolution

Gwenda Morgan

The Debate on the English Reformation

Rosemary O'Day

The Debate on the Decline of Spain

Helen Rawlings

The Debate on the English Revolution

R. C. Richardson

The Debate on the American Civil War Era

H. A. Tulloch

The Debate on the Crusades

Christopher Tyerman

The Debate on the Rise of the British Empire Anthony Webster

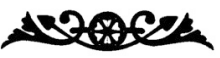


Issues in Historiography

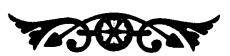

\title{
The Debate on Black Civil Rights in America
}

KEVERN VERNEY

\author{
MANCHESTER \\ UNIVERSITY PRESS
}


Copyright (C) Kevern Verney 2006

The right of Kevern Verney to be identified as the author of this work has been asserted by him in accordance with the Copyright, Designs and Patents Act 1988.

Published by Manchester University Press

Altrincham Street, Manchester M1 7JA, UK

www.manchesteruniversitypress.co.uk

British Library Cataloguing-in-Publication Data is available

ISBN 9780719067617 paperback

First published by Manchester University Press 2006

This edition first published 2017

The publisher has no responsibility for the persistence or accuracy of URLs for any external or third-party internet websites referred to in this book, and does not guarantee that any content on such websites is, or will remain, accurate or appropriate.

Printed in Great Britain

by CPI Group (UK) Ltd, Croydon CR0 4YY 